MaPan : Jurnal Matematika dan Pembelajaran

p-ISSN: 2354-6883 ; e-ISSN: 2581-172X

Volume 9, No 2, Dec 2021 (335-346)

DOI: https://doi.org/10.24252/mapan.2021v9n2a10

\title{
DIAGNOSIS OF STUDENTS' ERRORS IN FINDING AREAS BY INTEGRATION
}

\author{
Nurhasanah ${ }^{1)}$, Asdar Dollo2) \\ 1,2The Mathematics Education Study Program, Universitas Muhammadiyah Parepare \\ 1,2Jl. Jend. Ahmad Yani Km 6 Lapadde, Parepare, Indonesia \\ Email: hasanahnur705@gmail.com¹), asdardollo@gmail.com²)
}

Received October 01, 2021; Revised November 26, 2021; Accepted December 23, 2021

\begin{abstract}
:
This study aims to diagnose students' errors in finding the area using integration. Errors can be seen from the student completion steps that are not correct. This type of research is qualitative research. The applied instruments were diagnostic tests and interview guidelines. The subjects consisted of Universitas Muhammadiyah Parepare students from Mathematics Education Study Program. Then, the researchers selected three subjects from 23 subjects that committed various errors. The results showed that the errors were: (1) Conceptual error, (a) substitution errors for the lower bound and upper bound, (b) misunderstanding in drawing the graph of a function. (2) Procedural errors dealing with incorrect calculation operation. (3) Final solution errors dealing with incapability to find the accurate answers based on the questions. Therefore, it is necessary to diagnose errors made by students using integration to calculate the area so that for lecturers, it becomes a reference to minimize errors made by students and find solutions for the mistakes made.
\end{abstract}

Keywords: Error Diagnosis, Area, Integral

\section{DIAGNOSIS KESALAHAN MAHASISWA DALAM MENGHITUNG LUAS DAERAH DENGAN INTEGRAL}

\begin{abstract}
Abstrak:
Penelitian ini bertujuan untuk mengetahui kesalahan yang dilakukan mahasiswa dalam menghitung luas daerah menggunakan integral. Kesalahan yang terjadi dapat dilihat dari langkah-langkah penyelesaian mahasiswa yang masih kurang tepat. Jenis penelitian ini adalah penelitian kualitatif. Instrumen yang digunakan adalah tes diagnostik dan pedoman wawancara. Subjek dalam penelitian ini adalah mahasiswa Universitas Muhammadiyah Parepare Program studi Pendidikan Matematika. Selanjutnya, terpilih 3 orang subjek dari 23 orang subjek yang melakukan jenis kesalahan yang bervariasi. Hasil penelitian diperoleh bahwa jenis kesalahan yang dilakukan mahasiswa dalam menghitung luas daerah dengan menggunakan integral adalah (1) Kesalahan konsep, meliputi, (a) kesalahan dalam mensubtitusi nilai batas atas dan batas bawah, (b) kesalahan dalam menggambar grafik fungsi. (2) Kesalahan prosedur, yakni salah dalam melakukan operasi hitung. (3) Kesalahan penyelesaian akhir, yakni tidak menuliskan jawaban akhir dengan tepat sesuai yang ditanyakan soal. Olehnya itu perlu mengdiagnosis kesalahan yang dilakukan mahasiswa dalam
\end{abstract}

Copyright @ 2021, MaPan : Jurnal Matematika dan Pembelajaran 
penggunaan integral menghitung luas daerah sehingga bagi dosen menjadi referensi untuk meminimalisir kesalahan yang dilakukan mahasiswa dan menemukan solusi dari kesalahan-kesalahan yang dilakukan.

Kata Kunci: Diagnosis Kesalahan, Luas Daerah, Integral

How to Cite: Nurhasanah, \& Dollo, A. (2021). Diagnosis of Students' Errors in Finding Areas by Integration. MaPan : Jurnal Matematika dan Pembelajaran, 9(2), 335-346. https://doi.org/10.24252/mapan.2021v9n2a10.

\section{INTRODUCTION}

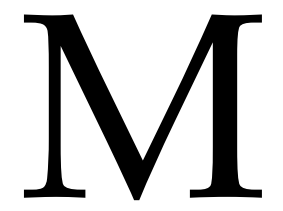

athematics is a science that studies abstract and hierarchical concepts (Mendezabal \& Tindowen, 2018). Because it is abstract, students often have difficulty in learning mathematics (Laurens, Batlolona, Batlolona, \& Leasa, 2018). Mathematics learning contains easy and difficult material for students to reach so that it can affect the achievement of learning objectives. Integral material is one of the materials taught in mathematics learning, from high school to university. Integral is very important to master (Serhan, 2015) that the material is taught in basic Mathematics and Calculus I courses. In studying the integral concept, there are several things that need to be understood, namely the number of areas, boundaries, areas, and other concepts. To understand integral concepts, students must connect concepts to construct new knowledge (Sholihah \& Maryono, 2020). In integral calculus, the competencies that are expected to be achieved are (1) understanding and being able to apply integral and indefinite concepts, (2) understanding integral techniques and applying them to problems, and (3) understanding indefinite integral concepts and proficient in solving problems (Sholihah \& Mubarok, 2016). The integral concept has many uses, such as determining an area, volume of a rotating object, length of a bow, etc. Gottfried Wilhelm Leibniz was the first author who developed and introduced the integral concept (anti-differential) for mathematics (146-1716 $\mathrm{M})$, famous with Leibniz. Integral is useful for mathematics and many fields, such as economy, astronomy, biology, physics, and many more. As a material of calculus subject, the integral has been learned by many educational levels, starting from the Senior High School until the University level. The skill consists of (1) calculating indefinite integral, (2) calculating definite integral on 
algebraic and trigonometry functions, (3) calculating the area, and (4) calculating the volume of rotating object (Amelia \& Yadrika, 2019).

Based on the researcher's experience teaching calculus subjects and interviews with students, the researchers noticed that some students had conceptual understanding problems and applications of integral in daily life. Research conducted by Solfitri, Kartini, Siregar, and Syari (2019) also shows that students experience errors in solving integral problems because students' understanding of basic concepts is still weak so that they understand the next concept. It proved that the students had inaccurate stages of solving the integral problems while calculating the area of an object. The learning difficulty was observable from the low test scores of the students. The difficulty of students in learning integral is the difficulty of understanding the language of mathematics, the limit is not only simple mathematical operations but many concepts that appear (Nursyahidah \& Albab, 2017). A poor understanding of the concepts of functions, limits and derivatives causes difficulties in learning integral (Dane, Cetin, Bas, \& Sagirli, 2016). They had errors while solving the integral questions to measure the given area of an object. Amelia and Yadrika (2019) supported this preliminary finding. The author found four types of errors that dominated the students. They were conceptual error, $36.75 \%$, operational error $(20 \%)$, principle error $(5 \%)$, and factual error (3.3\%). Syafmen (2015) explains the error types of the students in solving mathematics questions. The mistakes are (1) conceptual mistake, (2) incorrect data uses, (3) incorrect language interpretation, (4) technical error, and (5) error to conclude. Research conducted by Afifah, Ilman, and Putri (2018) that the students' problems in solving KPB questions include conceptual errors, operational errors, and principle errors.

In analyzing student errors, several indicators are needed so that the diagnosis process focuses on these indicators (Siregar \& Solfitri, 2019). Several opinions of previous researchers have been stated, the difference in this study is that the researcher uses the types of errors seen in solving integral problems to calculate the area divided into three aspects, namely (1) conceptual errors, (2) procedural errors, and (3) final resolution error. Conceptual errors in question are errors made in identifying the formula for the area of a region, and applying integral properties to solve area problems, procedural errors, namely errors in manipulating algebraic operations and calculation operations, final resolution errors, namely errors because they did not solve the problem until the final stage. Students must have excellent conceptual understanding 
and manipulating skills to promote the solving stage while calculating the area of an object with integral. Thus, they can provide incorrect final answers. One of the ways to find out the students' mistakes in solving questions is with a diagnostic test. This test is useful to determine and find the students' learning difficulties in learning a concept. The influential factors of the students' difficulties may cover the intellectual, emotional, physical, facilities or other factors (Husni, 2020; Onyema, Eucheria, Obafemi, Sen, Atonye, Sharma, \& Alsayed, 2020). Once the problem is found, the educators can provide a solution to improve the learning (Widoyoko, 2014). So, researchers need to diagnose errors made by students in the use of integrals to calculate the area so that for lecturers, it becomes a reference to minimize errors made by students and find solutions for the mistakes made. Thus, this research aims to diagnose the students' errors in finding the area by using integration.

\section{METHOD}

This type of research is qualitative research, which describes students' errors in solving integral problems and measuring the area. The subjects consisted of the 23 students of mathematics education, the University of Muhammadiyah Parepare, who have programmed calculus I and calculus II. The applied instruments were diagnostic tests and interviews. The data collecting technique was data triangulation. It combined two techniques of collecting data in the form of a diagnostic test in an essay and the interview. The applied data analyses were descriptive and narrative statistic analyses. The researchers obtained the quantitative data from the three questions of the diagnostic test of the students. Then, the researchers analyzed them with descriptive statistics in tables and graphs. Then, the qualitative data were obtained from the interview. The researchers analyzed the data narratively to make the interview understandable as information. Miles and Huberman (Sugiyono, 2019) explain that the data analysis consists of data reduction, display, and conclusion.

a. Data reduction consists of correcting answers to diagnostic tests; checking the results based on the size of the error in solving the problem. Researchers chose the collected data as initial data. Then the researcher chose the subject to proceed to the interview stage. The data collected from the diagnostic test results were used to select subjects for the interview stage. The three subjects selected were those who made various mistakes. The results of the interviews were transcribed into sentences. 
b. Data display consists of data collections of a diagnostic test as the interview materials. The researchers displayed the interview data results. Then, the researchers analyzed data from diagnostic tests and interviewed to answer the research problems. The data displayed in the table was from the descriptive analysis of the diagnostic test result. The data interview display took form as narrations of the obtained information by the researchers.

c. The researchers concluded based on the diagnostic test results and interview results about the error types and the causal factors of the errors.

\section{RESULTS AND DISCUSSION}

The diagnostic test and interview showed the subjects' errors and types of errors. Here is the error description based on the subjects.

\section{The Error Analysis of Subject 1}

The following shows the answers of subject 1 to question number 1 : "state the form of the formula for the area of the shaded area bounded by a graph."

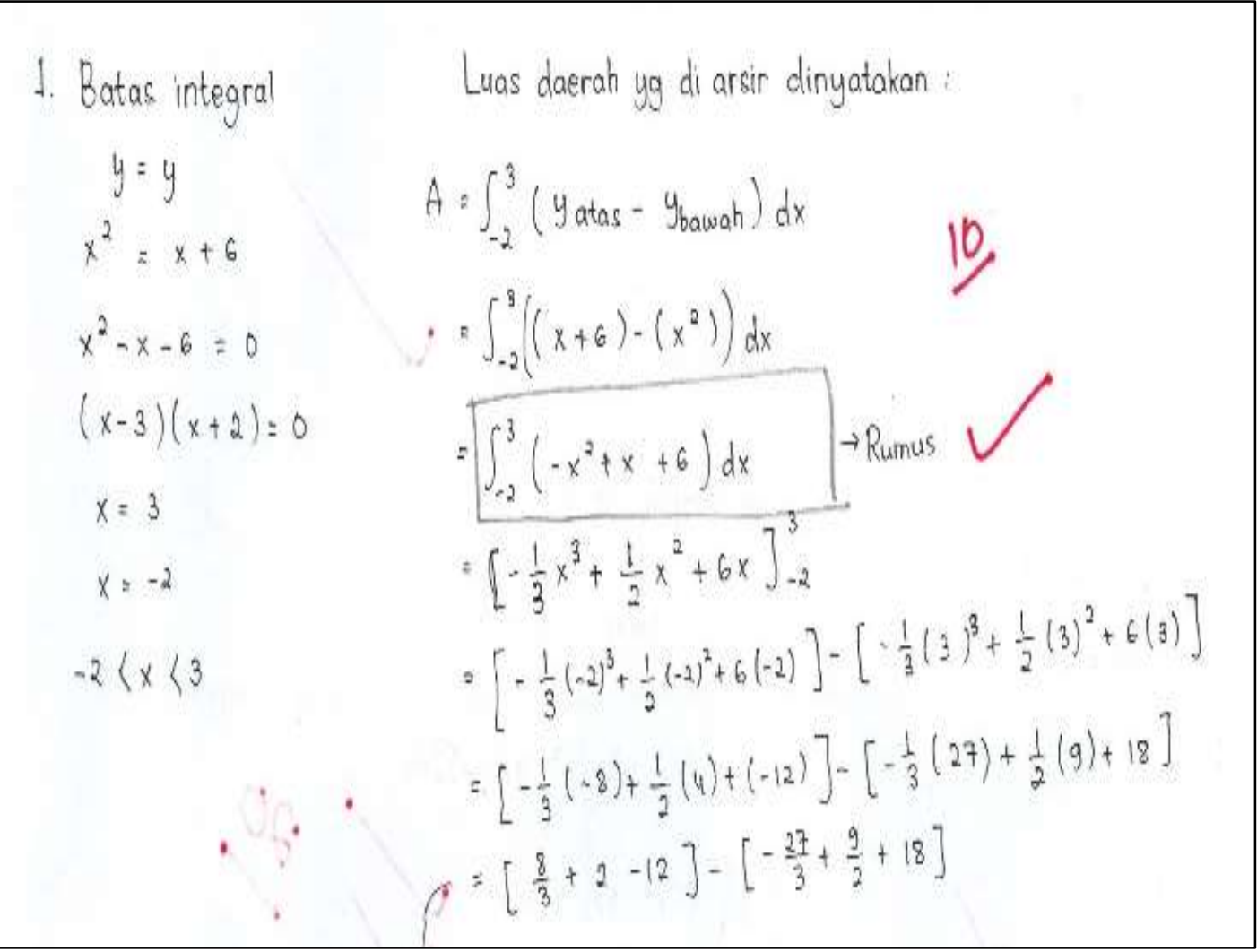

Figure 1. The Answer Numbered 1 - Subject 1 
The subject did not write the final answer based on the given question. It was the formula of the shaded area of the graph. The subject substituted the upper and lower bounds from the graph to get the final answer. The category of the error was a final-answer writing error.

The interview with subject 1 showed that he knew the given matter of the questions. The subject could solve the question with an integral definition. However, subject 1 incorrectly interpreted the final answer. This was the finalwriting error because the subject read inaccurately and carelessly while solving the question.

The following shows the answers of subje of question number 2 with "the question of finding the area of the shaded area on the graph."

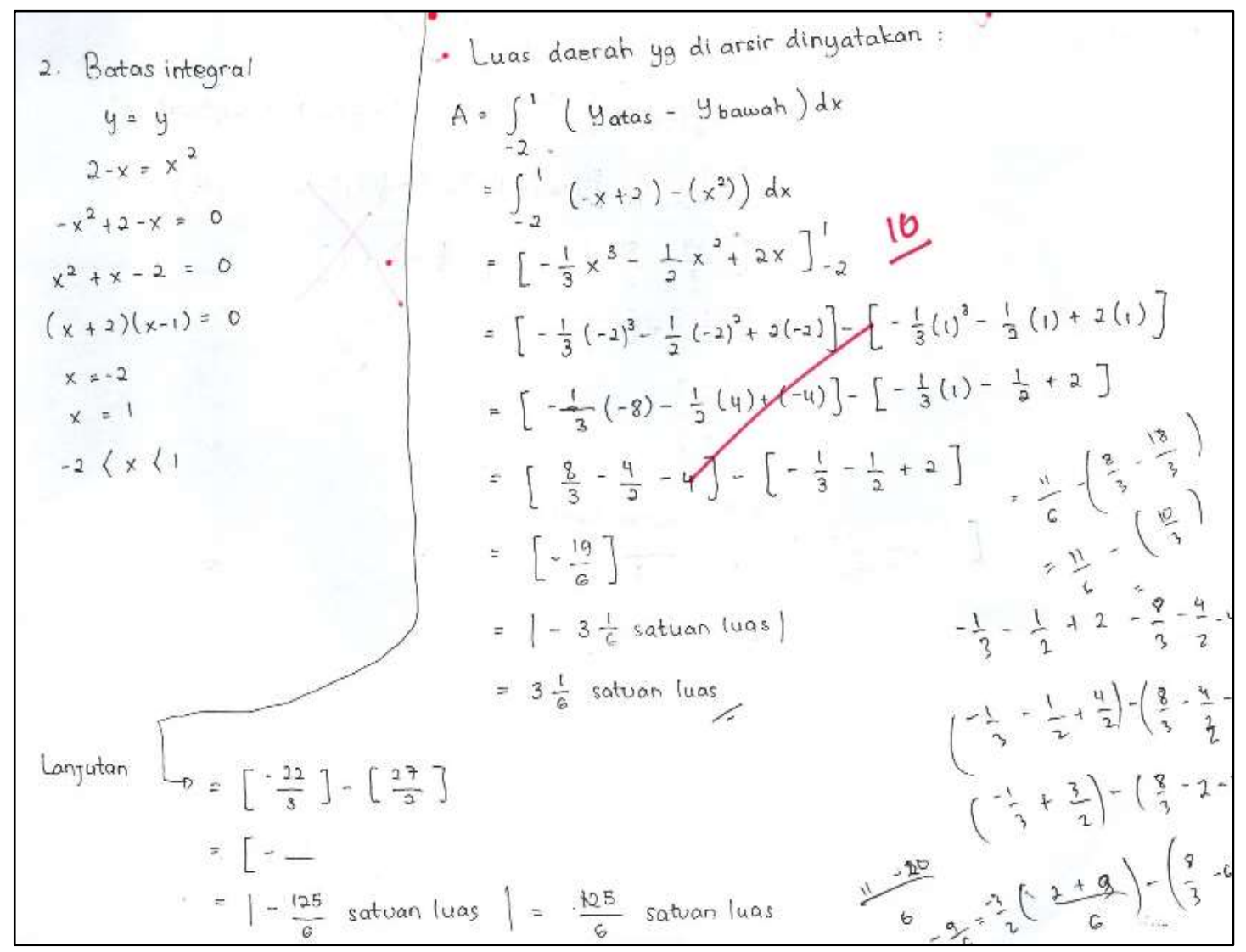

Figure 2. The Answer Numbered 2 - Subject 1

The subject wrote the given matter of the question and sought the integral limit based on the integral concept. The subject was aware of the given and the questioned things on the questions. The interview result also showed that the student could manipulate the algebra so that the integral result of the function was correct based on the integral basic principle. However, the 
subject made the error while substituting the lower values of certain integrals by substituting the lower bound value before the upper bound values. This finding showed the conceptual problems while solving specific integral. The causal factor was the lack of a specific integral concept in substituting the integral value bounds.

From the interview and test data reduction, the subject knew the given and questioned matters of the question. The subject could promote the integral solution operation, but the subject had an error substituting the integral value bounds. The error was the conceptual error.

The following shows the answers of subject 1 to question number 3 from the question of determining the area bounded by the line and graph the function.

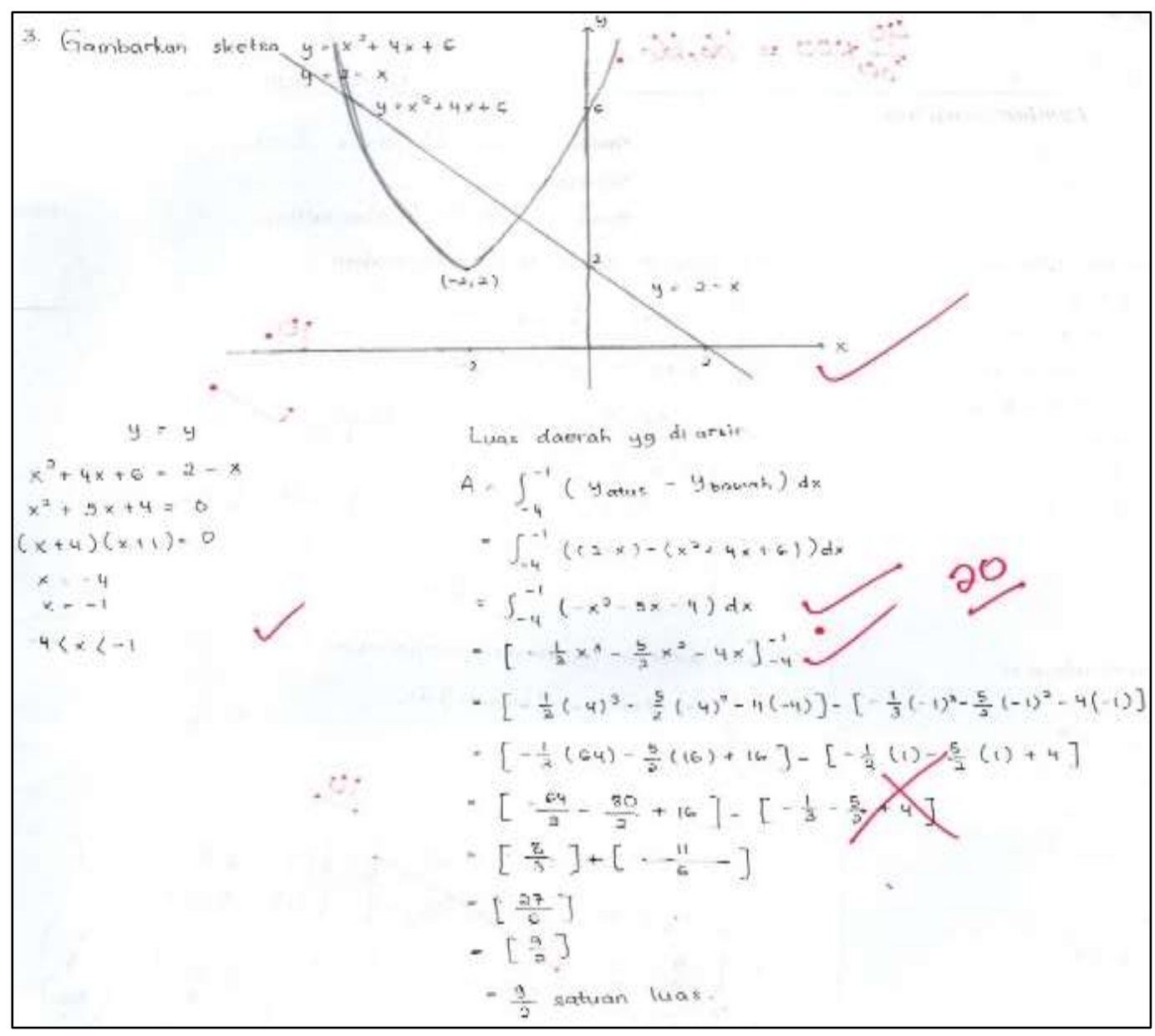

Figure 3. The Answer Numbered 3 - Subject 1

The subject incorrectly substituted the value bounds on the integral. The subject did it by substituting the lower bound before the upper bound values. This error referred to the conceptual error category on specific integral. The 
subject understood the given and questioned matters. The subject could describe the graph completely.

The interview showed that the subject could not draw the graph clearly, but the subject could manipulate the algebra. Thus, the integral result of the function was correct based on the integral principle. The error of the subject was substituting the value bounds of a specific integral. The subject did it by substituting the lower bound before the upper bound. This finding showed the conceptual problems while solving specific integral. The data reduction of the interview and test proved that the subject knew the given and the questioned matters in the questions. The subject knew how to find and do the integral solution operation. However, the subject incorrectly drew the graph clearly and incorrectly substituted the integral value bounds. The error was the conceptual error.

\section{The Error Analysis of Subject 2}

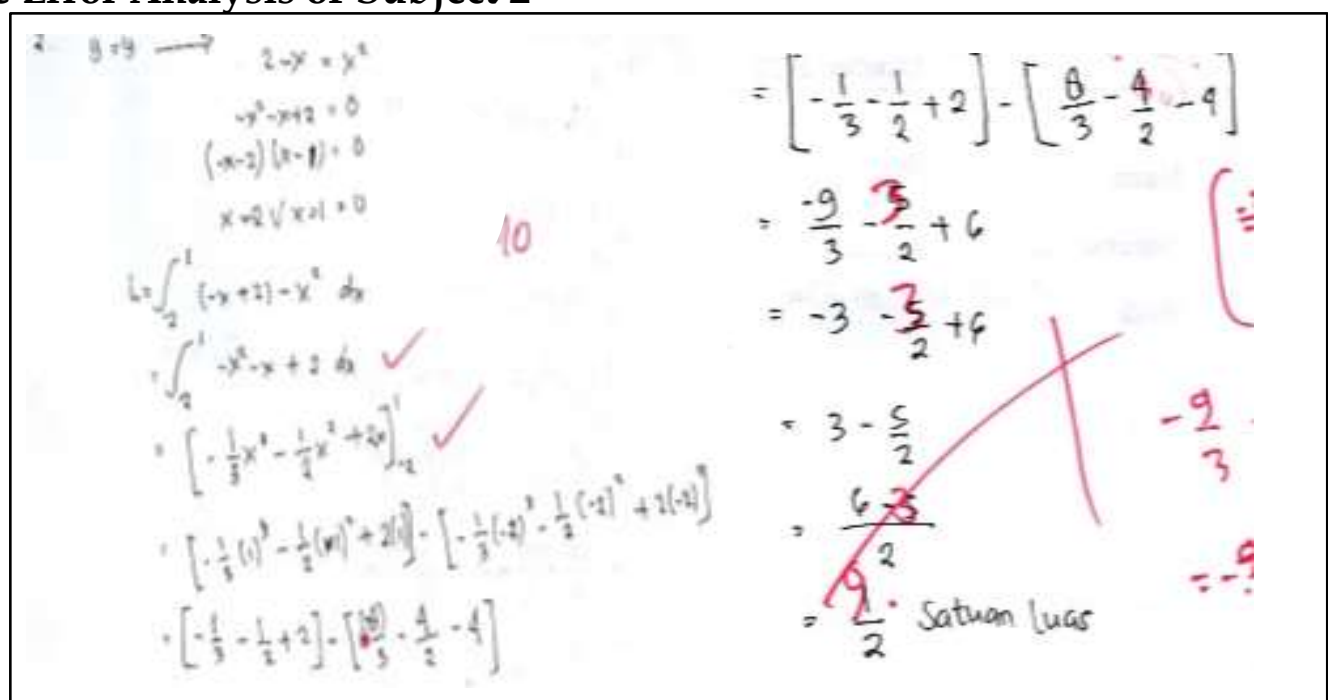

Figure 4. The Answer Numbered 2- Subject 2

Figure 4 shows the error analysis performed by subject 2. The error displayed by subject 2 is included in the procedural error, namely the error in performing arithmetic operations on fractional numbers. Subject 2 was the only subject who experienced errors in calculating fractional numbers in question number 2, and other subjects experienced different errors with the same number.

The data reduction of the interview and test proved that the subject knew the given and the questioned matters in the questions. The subject knew how to find and do the integral solution operation. However, the subject 
incorrectly drew the graph clearly and incorrectly substituted the integral value bounds. The subject knew and could solve the questions. However, the subject was incorrect in the calculation. This error was a procedural error that led to inaccurate answers.

The data reduction of the diagnostic test and interview obtained the subject could solve the integral questions with the integral principle and regulation. However, the subject was not carefully doing the calculation process. This error was a procedural error.

\section{The Error Analysis of Subject 3}

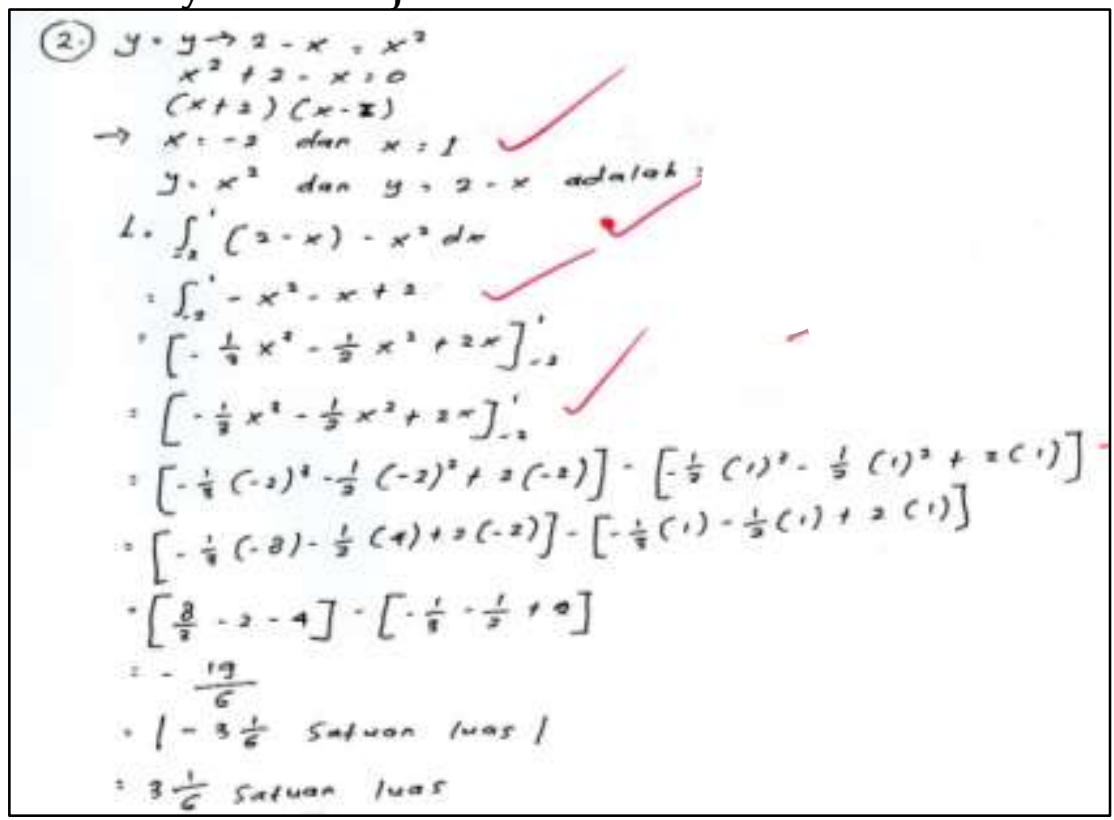

Figure 5. The Answer Numbered 2 - Subject 3

Figure 5 shows the error analysis performed by subject 3. The error displayed by subject 3 is included in the concept error, namely in substituting the value of integral limits. Subject 3 is the only subject who experiences substitution errors in question number 2, other subjects experience different errors with the same number.

The answer showed the subject knew the given and questioned matters and the value bounds of integral. Then, the subject made an error in substituting the integral's lower and upper bound values. It was a conceptual error due to the incorrect final answer. The main error was probably due to conceptual error on specific integral. The interview with subject 3 showed that the subject knew the given and questioned matters from the question. Then, the subject could explain the questions with the integral definition. However, the subject incorrectly distributed the integral bounds. The error type was the 
calculation process error. It occurred because the subject incorrectly operated the calculation by reversely substituting the lower and upper-value bounds.

The diagnostic test and interview data found that the subject could solve the integral questions with the integral principle and regulation. However, the subject was not carefully calculating the calculation process. The error type was procedural errors because the subject knew the concept but incorrectly distributed the value. Table 1 shows the data display and verification based on the error type.

Table 1. The Error Recapitulation and The Error Types of The Students in Calculating The Area by Integration

\begin{tabular}{clc}
\hline No. Questions & \multicolumn{1}{c}{ Descriptions of the Error } & \multicolumn{1}{c}{ Error Types } \\
\hline 1 & $\begin{array}{l}\text { The students could not write the area } \\
\text { of the integral formula based on the } \\
\text { questioned items. }\end{array}$ & $\begin{array}{c}\text { Committing } \\
\text { incorrect final } \\
\text { solution }\end{array}$ \\
& $\begin{array}{l}\text { The students reversely substituted the } \\
\text { value bounds of integral. } \\
\text { One of the errors was in calculating } \\
\text { operation. }\end{array}$ & $\begin{array}{c}\text { Conceptual error } \\
\text { The subject did not show the graphics } \\
\text { perfectly. }\end{array}$ \\
& $\begin{array}{l}\text { The students did not substitute the } \\
\text { integral value bounds reversely. They } \\
\text { put the lower bound first before the } \\
\text { upper bounds. }\end{array}$ & Conceptual error \\
& & \\
\hline
\end{tabular}

In general, the most frequent mistakes students make in calculating the area with the first integral is a conceptual error by not being able to substitute the upper and lower limit values correctly, which is most often done in solving problems number 2 and number 3. The second is a procedural error, namely, performing an incorrect calculation operation. The third is the final completion error, which is an error in writing the final answer.

\section{CONCLUSION}

The researchers concluded that the students' errors in solving the area by integration were (1) conceptual error, such as substituting the lower and upper bounds reversely and incorrectly drawing the function graph, (2) procedural error, such as incorrectly calculating, and (3) final-solution error, such as incorrectly writing the final answer based on the questioned item. 
The researchers suggest the students should have ice-breaking activity dealing with the previous materials before joining the Calculus I course; the students should receive a review about the primary requirement of function and the definite integral. Thus, the students would not have problems with the definite integral concepts. They need to understand the value bounds or intervals of definite integral and solve the definite integral before measuring the area.

\section{ACKNOWLEDGMENT}

Thank you to the University of Muhammadiyah Parepare, which has provided funds to researchers during this time.

\section{REFERENCES}

Afifah, D. S. N., Ilman, M., \& Putri, I. M. (2018). Analisis kesalahan mahasiswa dalam menyelesaikan soal kalkulus peubah banyak. MaPan: Jurnal Matematika Dan Pembelajaran, 6(2), 207-220. https://doi.org/10.24252/ mapan.2018v6n2a7.

Amelia, S., \& Yadrika, G. (2019). Analisis kesalahan siswa SMA dalam menyelesaikan soal integral. Jurnal Ilmiah Dikdaya, 9(1), 124-131. https://dx.doi.org/10.33087/dikdaya.v9i1.132.

Dane, A., Cetin, O. F., Bas, F., \& Sagirli, M. O. (2016). A conceptual and procedural research on the hierarchical structure of mathematics emerging in the minds of university students: An example of limitcontinuity-integral-derivative. International Journal of Higher Education, 5(2), 82-91. https:// doi.org/10.5430/ijhe.v5n2p82.

Husni. (2020). The effect of inquiry-based learning on religious subjects learning activities: An experimental study in high schools. Jurnal Penelitian Pendidikan Islam, 8(1), 43-54. https:// doi.org/10.36667/jppi.v8i1.434.

Laurens, T., Batlolona, F. A., Batlolona, J. R., \& Leasa, M. (2018). How does realistic mathematics education (RME) improve students' mathematics cognitive achievement? EURASIA Journal of Mathematics, Science and Technology Education, 14(2), 569-578. https:// doi.org/10.12973/ ejmste/ 76959.

Mendezabal, M. J. N., \& Tindowen, D. J. C. (2018). Improving students' attitude, cenceptual understanding and procedural skills in differential calculus through microsoft mathematics. Journal of Technology and Science Education, 8(4), 385-397. https://doi.org/10.3926/jotse.356. 
Nursyahidah, F., \& Albab, I. U. (2017). Investigating student difficulties on integral calculus based on critical thinking aspects. Jurnal Riset Pendidikan Matematika, 4(2), 211-218. https:// doi.org/10.21831/jrpm.v4i2.15507.

Onyema, E. M., Eucheria, N. C., Obafemi, F. A., Sen, S., Atonye, F. G., Sharma, A., \& Alsayed, A. O. (2020). Impact of coronavirus pandemic on education. Journal of Education and Practice, 11(13), 108-121. https://doi.org/10.7176/JEP/11-13-12.

Serhan, D. (2015). Students' understanding of the definite integral concept. IJRES: International Journal of Research in Education and Science, 1(1), 84-88. Retrieved from https:/ / files.eric.ed.gov/fulltext/EJ1105099.pdf.

Sholihah, U., \& Maryono. (2020). Students' visual thinking ability in solving the integral problem. Journal of Research and Advances in Mathematics Education, 5(2), 175-186. https://doi.org/10.23917/jramathedu.v5i2.10286.

Sholihah, U., \& Mubarok, D. A. (2016). Analisis pemahaman integral taktentu berdasarkan teori apos (action, process, object, scheme) pada mahasiswa tadris matematika (TMT) IAIN Tulungagung. Cendekia Jurnal Kependidikan Dan Kemasyarakatan, 14(1), 123-136. https://doi.org/10.21154/cendekia. v14i1.620.

Siregar, H. M., \& Solfitri, T. (2019). An analysis of students' errors in solving indefinite integral problems viewed from gender differences. Journal of Research on Mathematics Instruction, 1(1), 17-24. Retrieved from https://jrmi.ejournal.unri.ac.id/index.php/jrmi/article/view/12.

Solfitri, T., Kartini, Siregar, H. M., \& Syari, R. (2019). The analysis of students' errors in using integration techniques. Proceeding of the SS9 $\mathcal{E} 3$ rd URICES, 328-335. Pekan Baru.

Sugiyono. (2019). Metode penelitian pendidikan. Bandung: Alfabeta.

Syafmen, W. (2015). Identifikasi kesalahan siswa dalam menyelesaikan soal matematika di SMA (studi kasus SMAN 11 Kota Jambi). Kreatif, 17(3).

Widoyoko, E. P. (2014). Penilaian hasil belajar di sekolah. Yogyakarta: Pustaka belajar. 